\title{
Writing on the earth: Early European travellers to South Africa
}

Marilet Sienaert

Dept. of Afrikaans

University of Durban-Westville

DURBAN

\author{
Lindy Stiebel \\ Department of English \\ University of Durban-Westville \\ DURBAN
}

\begin{abstract}
"Writing on the earth" (Van der Watt, 1993:23): Early European travellers to South Africa

The issue of land in South Africa has always been problematic. This is to be expected in a country whose history has been one of colonisation, contested borders and, in the more recent apartheid past, of legalised removals of people from the land. In recent postcolonial theory too, the notion of spatiality has proved to be significant: to write a history of a country and its people is to write a spatial history through the processes of naming, mapping, classifying and painting. Our project in this article is to explore some of the ways in which early European travellers to South Africa traced their presence in this country, and in so doing began a chapter of "writing on the earth", the ideological marks of which linger on into this century.
\end{abstract}

\section{Introduction}

The issue of land in South Africa has always been problematical - to whom does it belong, who may live where, by what name should it be known? In a history which has been one of colonisation, contested borders and, in the more recent past, of mass displacements of people in the failed apartheid project of social engineering, the contested nature of South Africa's land is understandable. Currently, formerly displaced persons are undergoing the lengthy procedure of reclaiming land.

In recent post-colonial theory too, the notion of spatiality has proved to be significant: to write a history of a country and its people is to write a spatial history, an account of the experience of its land, its ownership, appropriation, its naming. Our project in this article is to suggest some of the ways in which early European travellers traced their presence in South Africa, a land foreign 
to them, and in so doing began a chapter of "writing on the earth" (Van der Watt, 1993:23), the ideological marks of which linger on in this century.

\section{Language and place}

Out of an abstract perception of space "out there" comes a perception of place. As Noyes (1993:122) in a review of Paul Carter's influential book The road to Botany Bay comments d propos the imperial enterprise: “... from an initial apprehension of the space of the new land, various practices are developed which produce places. These places exist by virtue of their ability to be integrated into the social structure and administrative apparatus of Empire".

Such organisation of place from space is done through language; language which anchors that light abstract balloon of space to a concrete set of compass points. As Coetzee (1988:7) remarks: "This landscape remains alien, impenetrable, until a language is found in which to win it, speak it, represent it". The question of course is which language? Whose language? For the travellers from Europe in the eighteenth and nineteenth centuries that question was not hard to answer, indeed it would not have arisen as a question at all. Confident of their place and function in the world, they were well equipped to encounter the unknown and render it knowable in European terms.

\section{Naming}

The primary act of reducing an unfamiliar land to familiar or at least recognisable status is by naming. Again Noyes (1993:122):

One of the most fundamental gestures in which the explorer creates permanent significance is by tying personal experience to the landscape in the act of naming. It is the name which gives space history. The name grants space significance by suspending the temporality implied in the very act of naming.

Not only is the naming of landscape features done for the discoverers themselves but for their peers, for in many cases travellers were travelling with an official task in mind, or with a view to publishing for a European readership their travel journals, maps and sketches. As examples, see Choisy (1687), De La Loubère (1691), De Rennefort (1710) and Sonnerat (1782) as representative of the many seventeenth and eighteenth century French travellers, most of whom were on official voyages to the East, with the exception of Tachard (1688) and Lacaille (1776) who had specific missions to South Africa. The irony involved in naming after "discovering" notable geographical features was that such features mostly had a "native" name and were known to the indigenous people. The French missionnary Arbousset (1836:113-114) 
illustrates this point in the account of his "discovery" of principal river sources in South Africa through which he claims to offer

... to geographical science our tribute of information, which is calculated to settle some questions, which, till now, have remained unsolved (...). We have satisfied ourselves that the rivers of which we are about to speak (...) take their rise in a mountain which the natives call Pofung (...) but which we have designated in our map by the name of 'Mont aux Sources'!

This irony is compounded by the joy certain travellers report as being expressed by their bearers and guides at finding what they already knew was there. Pratt (1992:205) wittily comments on this score that Africans in the employ of such travellers were thus "assign[ed] ... the task of carrying their masters' emotional baggage along with the rest of their stuff". While Pratt's examples in this regard are drawn from nineteenth century explorers in Central Africa, the principle of requiring physical - and, it seems at times, emotional - help from local dwellers on the route to discover features in a foreign land has wider application. ${ }^{2}$ In such inhabited lands the naming of geographical features by European travellers of places that already had a local name seems to illustrate Edward Said's (1993:xxii-xxiii) notion of rival geographies. This rivalry in nineteenth century explorers to Africa seems a little lopsided, however, as the Europeans clearly had faith in their own authority in possessing the master discourse in so far as their naming and thereby dominance went. Said (1993:xxiii xxiv) continues:

In your narratives, travel tales, and explorations your consciousness was represented as the principal authority, an active point of energy that made sense not just of colonising activities but of exotic geographies and people.

\section{Classifying}

One of the most important tools for ordering these "exotic geographies" and ultimately laying the foundations for the assurance of the later nineteenth

1 Tiffin and Lawson (1994:1) open their book De-scribing Empire with a similar example. Though not drawn from Africa, the general principle holds true: "On June 1953 news reached England that Tensing Norgay and a New Zealand companion, Hillary, had climbed the world's highest mountain, Chomolungma."

2 More locally similar examples can be quoted, for instance the nineteenth-century traveller Delegorgue (1990:221), who derives from his bearers both literal and emotional support, as when crossing leech-infested marshes in Natal he comments: "I decided that it would be more convenient to have my men carry me across. They found these baths delightfully refreshing". 
century travellers in Africa was the Swedish naturalist Carl Linnaeus' system of classification of plants, The system of nature (1753). ${ }^{3}$ His classification system was designed to enable the natural historian to make order out of chaos, to be able to assign a place in a hierarchy and a Latin name to every living plant. Parallel systems were also proposed for animals, minerals and eventually humans with "genetic" characteristics included. The language he chose for this system was Latin, with secular European "common" names:

One by one the planet's life forms were to be drawn out of the tangled threads of their life surroundings and rewoven into European based patterns of global unity and order. The (lettered, male, European) eye that held the system could familiarize ('naturalize') new sites/sights immediately upon contact, by incorporating them into the language of the system (Pratt, 1992:31).

In a similar vein, the French Jesuit astronomer Lacaille, who was on an official scientific mission to the Cape between 1751 and 1753 drew up a comprehensive catalogue of 9766 planets visible from that geographical region. By this token he had realigned the known European planetary grid to accommodate the unknown African skies. The repercussions for extended imperial sea travel were immense.

Before Linnaeus' system had taken hold, travellers to the Cape could engage on the terrain of Said's "rival geographies" in a less lopsided manner. The French traveller Tavernier (at the Cape in 1649) is able to show respect and gratitude to the Khoikhoi for their potentially life-saving skills in the use of medicinal plants (Tavernier, 1679:562) and also for their use of the "snake-stone" as a remedy for snake bite (compare Forbes, 1965:321-322). Later, Peter Kolb travelling in the Cape colony in 1706 to carry out astronomical and meteorological research uses his knowledge in tandem with local knowledge. He does not have at his disposal a European grid to superimpose over what he sees. $\mathrm{He}$ is interested in the medicinal qualities ascribed by the Khoikhoi to various plants such as the aloe, cannabis and ginseng root by the Khoikhoi, in how they might be used. As Pratt (1992:45) points out, Kolb's book The present state of the Cape of Good Hope (1719) "celebrates variety but shows no sign of a differentiating, classificatory impulse". Whilst his vocabulary to describe African land is European - "the plains and valleys are lovely

3 See note 19 in Pratt (1992:229). Pratt works from the 1956 British Museum facsimile edition of the 1758 edition of The system of nature. 
meadowlands ..." - he does not have access to the "heavy guns" of Latin classificatory tags. By way of contrast, two post-Linnaean travellers namely the Swede Sparrman (Voyages to the Cape of Good Hope, 1785) and the Scot Paterson (Narrative of four voyages in the Land of the Hottentots and Kaffirs, 1789), write accounts filled with precise observation followed by accurate classificatory naming:

When the heat of the day had passed, we made our way east-northeast, through an extremely arid country, leaving the immense chain of mountains to our right: forty miles away we observed another chain of mountains to our left. Though this country has an extremely arid appearance, it nevertheless abounds in plants of the euphorbe class, in orpin, mezembryanthimum, and several species of geranium (Paterson, as quoted in Pratt, 1992:51).

The land is seen through a powerful, knowledgeable, ordering grid which tames the potentially threatening "other" land hinted at in Paterson's repetition (and subtextual fear?) of "extremely arid country".

\section{Order through mapping}

In tandem with the confidence and power that naming accrues to the namer faced with seeming chaos, the process of mapping is instrumental in "writing on the earth". A map is a source of power through knowledge; it is the imposition of order on the unknown but suspected disorder of the blank page. It is never a neutral activity, for the mapper brings a subjective gaze to bear upon the space and selects that which is important to be mapped according to previously established subjective criteria.

Maps are a kind of language, or social product which act as mediators between an inner mental world and an outer physical world. But they are, perhaps first and foremost, guides to the mind-set which produced them. They are, in this sense, less a representation of part of the earth's surface than a representation of the system of cognitive mapping which produced them (Penn, 1993:23).

With mapping, however, the empiricist thrust of the Linneaen system of classifiying is given an extra political edge, especially with the age of imperialism and later colonisation for "the systematic surface mapping of the globe correlates with the expanding search for commercially exploitable resources, markets, and lands to colonize, just as navigational mapping is linked with the search for trade routes" (Pratt, 1992:30).

This sharpening of focus or purpose in mapping is evident in the work of John Barrow, personal secretary to Governor Macartney, who in 1797 was commissioned by the British state to provide an accurate map of the Cape in 
terms of its geography and general state. As Penn (1993:28) remarks, Barrow did not so much travel in the name of science, as in the name of colonialism. Setting off for the eastern frontier, Barrow proceeded to record in the most selfeffacing and, to his mind therefore, scientific manner, information about the land he covered: its geography, flora and fauna, yet, interestingly enough, relatively little about its indigenous inhabitants. Also in later maps (for example those of Delegorgue, 1847) the exotic animals take precedence over the, to him, less interesting humans, as reflected in the title: "Carte (...) indiquant les lieux qu'habitent les diverses éspéces d'animaux". Where Barrow does mention inhabitants, it is in regard to the borders of the map which he drew, implying "that they merit consideration primarily because of their potential to contest or disrupt the boundary line" (Penn, 1993:31). This detailing of human presence only in relation to the margin of the map unwittingly illustrates the borders' frailty and arbitrariness. Van der Watt (1993:30) asserts that "The borders become lines of demarcation between 'here' and 'there', between us and them, culture and savage nature, Self and Other". The Other is invisible until s/he is a threat, thereafter his/her presence is to be meticulously noted and ordered.

\section{Painting the landscape}

In tandem with mapping and naming of the land comes a frequent practice among early European travellers of not only "writing on the earth" but also sketching and painting the landscape they saw. In this vein many displayed or adopted the disembodied, passive gaze of what Pratt (1992:7) calls "the seeing man": the European (male) subject of travel writing "whose imperial eyes passively look out and possess".

The apparent purpose of this scanning eye is deceptively simple: land has to be seen before it can be described, and the travelled country seems to have no existence of its own unless aesthetically observed and then transposed into text or visual image. Sometimes the pleasure of the sight is sufficient in itself to make the journey significant, as when Burton (as quoted in Pratt, 1992:204) writes: "Truly, it was a revel for soul and sight! Forgetting toils, dangers, and the doubtfulness of return, I felt willing to endure double what I had endured ...". This seemingly open stance of the travel writer as passive observer conveys a sense of innocence, as if nothing is demanded of the land in return. But such a self-effacing attitude serves the imperial purpose by effectively presenting information in such a way as to seem "natural", to have the wealth (mineral, botanical, ethnographical etc.) of the land seen to present itself freely, rather than to have it openly recognised as potential sites of appropriation. 
To convey information in a way that would seem as natural as possible, it therefore made sense to present the unknown in familiar European aesthetic terms, for example by using words and phrases freely borrowed from the Romantic poetic tradition: "The waters of the majestic river, flowing in a broad expanse resembling a smooth translucent lake, seemed, with their gentle waves, to kiss the shore ... bearing on their limpid bosom the image of their woodclothed banks ..." (Burchell as quoted in Coetzee, 1988:38).

However, some features of landscape description by these apparently transparent conveyers of information belie a neutral, unthreatening stance. The land is often physicalised through description, given female features, and often appropriated by scrutiny, as in the telling phrase of "opening up" the African continent, where "the eye commands (...) and mountains and valleys show themselves" (Barrow as quoted in Pratt, 1992:60).

The spread-out panorama of new territory thus exposed is furthermore often described as seen from a hill-top, thereby suggesting a relationship of domination in which new territory appropriately takes up the lower position:

The river immediately beneath us was invisible because of the steep drop; beyond was a beautiful luxuriant forest, while in the distance stretched a vast green plain, (...). Such a scene, which recalled the earliest days of creation, can today only be chanced upon where men are few and the innocent echoes repeat no sound of gunfire (Delegorgue, 1990:221).

Coetzee (1988:46) stresses the way in which this hill-top stance of the observer is typically linked to the painterly way in which the seeing proceeds, a process which supports the notion of the seer's mastery over the seen (refer also Pratt, 1992:204-205). The authority of the viewer remains unquestioned. As in the case of a painting, the viewer-as-artist sees all there is to see; his particular position is offered as the only possible vantage point. The landscape is static as it is viewed only from the traveller's position. Thus fixed, the land is reduced to object-to-be-analysed by the confident gaze of the observer.

From this it follows that the mastery of the seer over the seen is contained in the unquestioned authority to evaluate aesthetically, thereby revealing the interaction of aesthetics and ideology (refer Pratt, 1992:205). By inscribing the rough African landscape into the European painterly tradition of the picturesque, where pictorial principles are conveniently used to describe the scene in terms of foreground, middle ground and far distance (refer Coetzee, 1988:37 and 39), the landscape is thus "controlled" by the viewer: s/he only needs to see in terms of what $\mathrm{s} / \mathrm{he}$ has been taught to expect. 
The authority of the European gaze never falters. Even when recognising the inherent topographical difference of the land, and even when consciously striving to establish an African aesthetic, as for instance Le Vaillant (1972:196) attempts in the following passage, “... what are your [Europe's] purling streams, your cascades, your artificial mounts (...) all those objects which flatten on the sense, and fatigue the eye - what are ye when compared to the simple unaffected beauties of Pampoen Kraal!", the result is little more than a modified version of the European convention.

Colour is still defined by its lack in comparison with the hues of Europe, as when Burchell (as quoted in Coetzee, 1988:42) writes: "In Africa we look in vain for those mellow beautiful tints with which the sun of autumn dyes the forests of England ...". Similarly the open African sky, because it contrasts with the abundance of cloud movement over Europe, is said to render the landscape static, and leads to it being characterised repeatedly as "sleeping, torpid, heatstruck" (Coetzee, 1988:43), with emphasis on its immobility.

While the aesthetic value of the unfolding landscape indicates the material value of the "newly discovered" land to the explorers' home culture, its aesthetic shortcomings point the way for social and/or material intervention (refer Pratt, 1992:205). As the observer fixes the landscape within his European aesthetic framework, he often projects possible "improvements" to be brought about in the future, as in the telling example of a swamp "that by one single drain might be converted into a very beautiful meadow" (Barrow as quoted in Pratt, 1992:61).

Such proposals for "improvement" or economic development are so widespread in nineteenth century travel writing that Pratt (1985:126) places them within a special category of "the reverie convention". They spring from felt authority concealed behind the quietly passive scanning eye.

\section{Myth of the "empty" landscape}

But within the frame of these landscape descriptions and paintings Pratt (1992:51) is prompted to ask: "Where is everybody?". We have already commented on the invisibility of indigenous African inhabitants in the maps of Barrow and Delegorgue, that is, until the vulnerable borders are described and then the potentially troublesome "wilde Bosjemans and Hottentots" as Barrow names them appear. This myth of the empty landscape is in a sense the reverse action of "writing on the earth"; it is an erasing, a rubbing out. Tiffin and Lawson (1994:5) forward reasons as to why, in an era of colonialism which impelled many travellers to Africa, this myth was necessary: 
Colonialism conceptually depopulated countries either by acknowledging the native but relegating him or her to the category of the subhuman, or simply by looking through the native and denying his/her existence. These were necessary practices for invoking the claim of 'terra nullius' upon which the now disputed legality of imperial settlement (as opposed to invasion) was based. Only empty spaces can be settled, so the space had to be made empty by ignoring or dehumanizing the inhabitants.

The blank spaces on the map and the stylized landscape sketches and paintings call out to be peopled, but not by those currently there, rather by what Coetzee (1984:9) calls "an ideal community". "Ideal" in eighteenth and nineteenth century European terms one would imagine to mean non-African, in other words people versed in European ways and discourse rather than African culture. It is tempting to conjecture that prior to the validity of Linneaen systems of classification being accepted, Africans were more positively visible to Europeans. In Peter Kolb's previously mentioned pre-Linneaen account of his travels in the Cape, his interest is in seeking out the Khoikhoi and studying their way of life. Though he does not describe the Khoikhoi in terms of equality with the Europeans he is able to do something that seems impossible once the classificatory grids, Latin names and starkly outlined maps were in place: he is able to "[insist] they be understood by Europeans in the same terms Europeans understand themselves" (Pratt, 1992:44). ${ }^{4}$ Perhaps this was possible because the rivalry over contested geographies had not yet intensified to the pitch that was to come. Linnaeus' 1759 classification of Africans as "governed by caprice", Paterson's pronouncement of African peoples as being "sans moeurs" or cultureless, start to change the lenses through which Europeans beheld Africans, leading ultimately to the blindness of empty landscape in which it is only the flora, fauna and mute geology which remain visible to the gaze.

In conclusion, one could argue that despite the epistemological and aesthetic gains "writing on the earth" has brought in terms of being able to identify and name plant species, in mapping the land and in painting the landscape, a high price has been paid for this. In particular the obscuring of indigenous inhabitants in the "empty landscape" due to a "failure of the historical

4 De Beaulieu (in De Thevenot 1666:8), Tavernier (1679:560) and De Rennefort (1710:304-305) are some of the early French travellers who, although they express their aversion to some of the Khoikhoi's "strange" practices, are able to describe them in terms of different but not conquered people. 
imagination" as Coetzee (1984:9) calls it, is "the source of potential nightmare". The gazer

... scans the landscape with his hermeneutic gaze, but it remains trackless, refuses to emerge into meaningfulness as a landscape of signs. He speaks, but the stones are silent, will not come to life. Or when this is not true, when the stones seem on the point of coming to life, they do so in the form of some giant or monster from the past, wordless but breathing vengeance (Coetzee, 1988:9-10).

Naming, mapping, painting have all been used as ways of keeping the monster of chaos, the nameless dread at bay. These inscriptions have been enduring as Africa's inheritance and, in many instances maintenance of colonial boundaries and borders attests. But as the title "writing on the earth" implies, such marks cannot be permanent as shifts in power formations re-draw, re-name and reinscribe the land to match the day.

\section{References}

Arbousset, T. 1836. Narrative of an exploratory tour to the North-East of the Colony of the Cape of Good Hope. Translated by J. Crombie Brown. London : s.n.

Coetzee, J.M. 1988. White writing. On the culture of letters in South Africa. New Haven and London : Yale University Press.

Choisy, F. 1687. Journal du voyage de Siam fait en 1685 et 1686 . Paris.: s.n.

De La Loubère, S. 1691. Du royaume de Siam. Amsterdam : s.n.

De Thẻvenot, Melchisedeck. 1666. Rélation de divers voyages curieux. Part II. Paris : s.n.

Delegorgue, A. 1990. Travels in Southern Africa. Translated by F. Webb. Durban : Natal University Press.

Delegorgue, A. 1847. Voyage dans Afrique australe, notamment dans le territoire du Natal. Paris : s.n.

De Rennefort, Urbain Souchu. 1710. Histoire des Indes orientales, contenant outre l'établissement de la Compagnie de France, diverses particularités du Païs très-remarquables. Amsterdam : s.n.

Forbes,V.S. 1965. Pioneer travellers of South Africa: a geographical commentary upon routes, records, observations and opinions of travellers at the Cape, 1750-1800. Cape Town : Balkema.

Lacaille l'abbé de. 1776. Journal historique du voyage fait au Cap de Bonne Espérance. Paris : s.n.

Le Vaillant, F. 1972. Travels from the Cape of Good Hope, into the interior parts of Africa, including many interesting anecdotes. With elegant 
plates, descriptive of the country and inhabitants. New York : Johnson Reprint Corporation.

Noyes, J.K. 1993. The representation of spatial history. Pretexts, 4 (2):120127, Summer.

Paterson, W. 1789. Narrative of four voyages in the land of the Hottentots and Kaffirs. London : s.n.

Penn, N. 1993. Mapping the Cape: John Barrow and the First British Occupation of the Colony, 1795-1803. Pretexts, 4 (2):20-43, Summer.

Pratt, Mary Louise. 1985. Scratches on the face of the country; or, What Mr. Barrow saw in the land of the Bushmen. Critical Inquiry, 12:119-143, Autumn.

Pratt, Mary Louise. 1992. Imperial eyes: Travel writing and transculturation. London and New York : Routledge.

Said, Edward. 1993. Culture and imperialism. London : Chatto and Windus.

Sonnerat. 1782. Voyage aux Indes Orientales et à la Chine. Paris : s.n.

Sparrman, Anders. 1785. Voyage to the Cape of Good Hope. London : s.n.

Tachard, G. 1688. Voyages de Siam des Pères Jésuites. Paris : s.n.

Tavernier, Jean. 1679. Les six voyagages de Jean Baptiste Tavernier. Part II. Paris : s.n.

Tiffin, C. \& Lawson, A. (eds.) 1994. De-scribing Empire. London : Routledge.

Van der Watt, Liese. 1993. Thomas Baines and the colonisation of space. De Arte, 48:23-31. 
